\title{
PENINGKATAN KEMAMPUAN KOMUNIKASI MATEMATIS SISWA DENGAN MENGGUNAKAN MODEL PEMBELAJARAN STUDENT FACILITATOR AND EXPLAING (SFE) DI KELAS XI SMA NEGERI 8 TAKENGON
}

\section{Lola Mandasari}

STAIN Gajah Putih Takengon, Aceh Tengah, Aceh

Email: aai_za@yahoo.com

\begin{abstract}
Abstrak. Tujuan yang ingin dicapai dalam penelitian ini adalah untuk mengetahui adakah peningkatan kemampuan komunikasi matematis siswa setelah dilakukannya pembelajaran dengan model Student Facilitator and Explaining (SFE). Metode penelitian ini adalah semi eksperimen dengan pendekatan kuantitatif. Populasi pada penelitian ini adalah seluruh siswa kelas XI SMA Negeri 8 Takengon tahun ajaran 2018/2019. Pengambilan sampel pada penelitian ini menggunakan teknik cluster random sampling dan terpilih siswa kelas XI Mipa-1 dengan jumlah 21 siswa dan kelas XI Mipa-2 dengan jumlah 20 siswa. Teknik analisis data yang dilakukan adalah uji normalitas, uji homogenitas dan uji gain ternormalisasi. Hasil penelitian menunjukkan bahawa : (1) Siswa dari kelas eksperimen dengan skor gain $>0.70$ berjumlah 18 orang dengan kategori tinggi (90\%) (2) Siswa dari kelas eksperimen dengan $0.30<$ skor gain $<0.70$ berjumlah 2 orang dengan kategori sedang (10\%) (3) Siswa dari kelas eksperimen dengan skor gain $<0.30$ berjumlah 0 orang atau tidak terdapat siswa yang memperoleh skor gain dibawah 0,30 dengan kategori rendah.
\end{abstract}

Kata kunci: peningkatan kemampuan komunikasi matematis, model pembelajaran student facilitator and explaing (sfe).

\section{Pendahuluan}

Matematika merupakan pelajaran wajib yang dipelajari dari jenjang SD sampai universitas. Matematika juga memiliki andil yang besar dalam memberikan berbagai kemampuan kepada siswa diantaranya: kemampuan berfikir, kempuan memecahkan masalah serta kemampuan komunikasi matematis siswa. Menurut Purnama Ramlan, matematika memiliki peran sebagai bahasa simbolik yang memungkinkan terwujudnya komunikasi secara cermat dan tepat. Matematika tidak hanya sekedar alat bantu berfikir tetapi matematika sebagai wahana komunikasi antar siswa dan guru dengan siswa ${ }^{1}$. Semua orang diharapkan dapat menggunakan bahasa matematika untuk mengkomunikasikan informasi maupun ide-ide yang diperolehnya. Matematika itu sendiri pada hakikatnya adalah simbol. Oleh karena itu, kesulitan dalam bahasadapat berpengaruh terhadap kemampuan anak dibidang matematika. Soal matematika yang berbentuk cerita menuntut kemampuan membaca untuk memecahkannya. Dalam buku yang dikarang oleh Mulyono, guru hendaknya mampu menditeksi berbagai tipe kesulitan belajar siswa. Dengan demikian, pembelajaran dapat diarahkan pada perbaikan kekeliruan-kekeliruan tersebut. Menurut Mulyono, guru harus memeriksa pekerjaan siswa dan meminta siswa untuk menjelaskan bagaimana ia sampai pada penggunaan

\footnotetext{
${ }^{1}$ Purnama Ramlan, Dkk, "Kemampuan Komunikasi Matematis dan Pembelajaran Interaktif . Jurnal UNP vol 1. No. 1 (2012).
} 
pemecahan masalah seperti itu ${ }^{2}$. Guru juga perlu melakukan observasi terhadap cara yang digunakan dalam proses pembelajaran dan melakukan perbaikan terhadap kekeliruan tersebut.

Mengkomunikasikan gagasan dengan bahasa matematika justru lebih praktis, sistematis dan efisien. Setiap siswa harus belajar matematika dengan alasan bahwa matematika merupakan alat komunikasi yang sangat kuat, sistematis dan tepat karena matematika sangat erat dengan kehidupan kita. Dengan megubah cara berbicara pada siswa tentang matematika. Jika seorang guru menginginkan mereka mengingat kosakata baru, guru harus menyuruh mereka menjelaskan arti kata tersebut kepada gurunya dengan menggunakan bahasa mereka sendiri dan kemudian meminta seorang siswa untuk menjelaskan di depan kelas. Hal inilah yang disebut dengan kemampuan komunikasi matematis siswa. Menurut Armiati yang di kutip oleh Astuti, "komunikasi matematis adalah suatu keterampilan penting dalam matematika yaitu kemampuan untuk mengekspresikan ide-ide matematika secara koheren kepada teman, guru, dan lainnya melalui bahasa lisan dan tulisan"3. Dengan menggunakan bahasa matematika yang benar untuk berbicara dan menulis tentang apa yang mereka kerjakan, mereka akan mampu mengklarifikasi ide-ide mereka dan belajar bagaimana membuat argument yang meyakinkan dan mempresentasikan ide-ide matematika.

Tapi kenyataan dilapangan menunjukkan bahwa kemampuan komunikasi matematis siswa masih rendah yaitu siswa kurang merespon dan tidak aktif dalam kegiatan pembelajaran, para siswa juga mengalami kesulitan untuk menyelesaikan soal yang disajikan, khususnya siswa mengalami kesulitan menyelesaikan soal dalam bentuk cerita. Dari hasil observasi aawl yang dilakukan menunjukkan bahwa kemampuan komunikasi siswa yang masih rendah, dengan kata lain siswa kurang mampu mengkomunikasikan permasalahan (soal) yang diberikan kepadanya sehingga sulit memberikan solusi terhadap permasalahan yang di berikan kepadanya, sehingga sulit memberikan solusi terhadap permasalahan yang di berikan.

Salah satu penyebab rendahnya kemampuan rendahnya kemampuan siswa bisa dikatakan selama ini guru hanya memberi informasi baru kepada siswa melalui ceramah, kemudian memberi soal-soal latihan untuk dikerjakan siswa, hal ini bersifat rutin dilakukan di sekolah sehingga menyebabkan siswa tidak dapat mengungkapkan ide dan gagasannya dalam wujud lisan maupun tulisan. Seperti yang kita alami di kelas-kelas masih menitik beratkan kepada pembelajaran langsung yang pada umumnya didominasi oleh guru, siswa masih secara pasif menerima apa yang diberikan oleh guru, umumnya hanya satu arah. Beberapa ahli mengatakan bahwa dalam pembelajatran matematika umumnya siswa menonton gurunya menyelesaikan soal-soal di papan tulis. Pola-pola pembelajaran transmisi masih mendominasi kelas misalnya guru mengenalkan aturan umum dalam matematika dan dilanjutkan dengan memberikan soal-soal latihan. Maka dalam hal ini kemampuan komunikasi matematis siswa masih sangat perlu ditingkatkan atau dengan kata lain kemampuan komunikasi matematis sungguh sangat dibutuhkan.

Berdasarkan uraian di atas, maka masalah yang muncul adalah model pembelajaran apa yang dapat dikembangkan guru dalam meningkatkan kemampuan komunikasi matematis siswa? Sehingga, penulis tertarik untuk menggunakan model

\footnotetext{
${ }^{2}$ Mulyono Abdurrahman, Pendidikan Bagi Anak Kesulitan Belajar, (Jakarta: PT Asdi Mahasatya, 2010), hal. 271

${ }^{3}$ Anggraini Astuti, "Peran Kemampuan Komunikasi Matematika Teradap Prestasi Belajar Matematika Siswa”, Jurnal Formatif 2 (2): 102-110, ISSN 2088-351X, hal. 104.
} 
pembelajaran yang mampu meningkatkan kemampuan komunikasi matematis siswa yaitu model pembelajaran Student Facilitator and Explaing (SFE). Student Facilitator and Explaing(SFE) adalah model pembelajaran dimana siswa/peserta didik belajar mempresentasikan ide atau pendapat pada peserta didik lainnya. Model pembelajaran ini efektif untuk melatih siswa berbicara. Dengan demikian, proses pembelajaran yang dirancang dapat lebih bervariatif, lebih bermakna, menantang sekaligus menyenangkan.

Tujuan yang ingin dicapai dalam penelitian ini adalah untuk mengetahui adakah peningkatan kemampuan komunikasi matematis siswa setelah dilakukannya pembelajaran dengan model Student Facilitator and Explaining (SFE).

\section{Metodologi}

Metode yang digunakan pada penelitian ini adalah metode semi eksperimen dengan pendekatan kuantitatif. Penelitian ini dilaksanakan pada siswa kelas XI SMA Negeri 8 Takengon. Sampel penelitian ini terdiri dari siswa kelas Mipa-1 dengan jumlah 21 siswa dan siswa kelas XI Mipa-2 dengan jumlah 20. Instrumen yang digunakan adalah tes kemampuan komunikasi matematis. Data yang dianalisis adalah hasil dari tes kemampuan komunikasi pada materi komposisi fungsi. Teknik analisis data yang dilakukan adalah uji normalitas, uji homogenitas dan uji gain ternormalisasi. Sumber data penelitian ini adalah siswa kelas XI SMA Negeri 8 Takengon sebagai subjek penelitian. Keabsahan data yang digunakan adalah validitas dan reliabilitas instrumen penelitian.

Adapun indikator komunikasi matematis siswa pada penelitian ini dideskripsikan sebagai berikut:

Tabel 1. Indikator Komunikasi Matematis

\begin{tabular}{|c|c|c|}
\hline Kompetensi Dasar & $\begin{array}{l}\text { Indikator Komunikasi } \\
\text { Matematis }\end{array}$ & $\begin{array}{l}\text { Indikator Pencapaian } \\
\text { Kompetensi (IPK) }\end{array}$ \\
\hline $\begin{array}{l}\text { Mendeskripsikan konsep } \\
\text { komposisi fungsi dengan } \\
\text { menggunakan konteks } \\
\text { sehari-hari dan } \\
\text { menerapkan. } \\
\text { Mengolah data masalah } \\
\text { nyata dengan menerapkan } \\
\text { aturan operasi dua fungsi } \\
\text { atau lebih dan menafsirkan } \\
\text { nilai variabel yang } \\
\text { digunakan untuk } \\
\text { memecahkan masalah. } \\
\text { Memilih strategi yang } \\
\text { efektif dan menyajikan } \\
\text { model matematika dalam } \\
\text { memecahkan masalah } \\
\text { nyata terkait fungsi invers } \\
\text { dan invers fungsi. }\end{array}$ & $\begin{array}{l}\text { Kemampuan } \\
\text { mengekspresikan ide-ide } \\
\text { matematika melalui lisan, } \\
\text { tulisan dan } \\
\text { mendemonstrasikannya serta } \\
\text { menggambarkannya secara } \\
\text { visual. }\end{array}$ & $\begin{array}{l}\text { Mengidentifikasi } \\
\text { konsepkomposisi fungsi } \\
\text { Mendeskripsikan konsep } \\
\text { komposisi fungs } \\
\text { Mengubah masalah nyata } \\
\text { dengan menerapkan } \\
\text { aturan operasi dua fungsi } \\
\text { ataulebih dan menafsirkan } \\
\text { nilai variabel yang digunakan } \\
\text { untuk memecahkan masalah. }\end{array}$ \\
\hline
\end{tabular}




\begin{tabular}{|l|l|l|}
\hline & $\begin{array}{l}\text { Kemampuan memahami, } \\
\text { menginterprestasikan, dan } \\
\text { mengevaluasi ide-ide } \\
\text { matematika baik secara lisan } \\
\text { maupun dalam bentuk visual } \\
\text { lainnya. }\end{array}$ & $\begin{array}{l}\text { Mengkonstruksi strategi yang } \\
\text { efektif dan menyajikan model } \\
\text { matematika dalam } \\
\text { memecahkan masalah nyata } \\
\text { terkait fungsi invers dan } \\
\text { invers fungsi. }\end{array}$ \\
\cline { 2 - 3 } $\begin{array}{l}\text { Merancang mengajukan } \\
\text { masalah dunia nyata yang } \\
\text { berkaitan dengan } \\
\text { komposisi fungsi dan } \\
\text { menerapkan berbagai } \\
\text { aturan dalam } \\
\text { menyeleaikannya. }\end{array}$ & $\begin{array}{l}\text { Kemampuan meggunakan } \\
\text { istilah, notasi matematika } \\
\text { dan struktur-strukturnya } \\
\text { untuk menyajikan ide, } \\
\text { menggambarkan hubungan } \\
\text { dan model situasi }\end{array}$ & $\begin{array}{l}\text { Mengubah masalah dunia } \\
\text { kentuk nyata. } \\
\text { nyata yang berkaitan dengan }\end{array}$ \\
& $\begin{array}{l}\text { Menghubungkan kedalam } \\
\text { aturan dalam menyelesaikan } \\
\text { masalah dunia nyata yang } \\
\text { berkaitan dengan komposisi } \\
\text { fungsi. }\end{array}$ \\
\hline
\end{tabular}

\section{Hasil dan Pembahasan}

Hasil penelitian yang dilakukan pada kelas XI SMA Negeri 8 Takengon. Tes yang diberikan terdiri dari tes awal (pretest) dan tes akhir (posttest), pretest diberikan kelas eksperimen dan kontrol dengan tujuan untuk mengetahui tingkat kemampuan awal siswa mengenai materi Komposisi Fungsi dan Invers Fungsi.

Selanjutnya tes akhir diberikan pada kelas eksperimen dan kelas kontrol sesudah proses belajar mengajar yang diberikan peneliti terhadap siswa dengan perlakuan yaitu untuk kelas eksperimen menggunakan model pembelajaran Student Facilitator and Explaining (SFE), sedangkan kelas kontrol menggunakan metode pembelajaran konvensional, materi yang diberikan untuk tes akhir adalah materi Komposisi Fungsi dan Invers Fungsi. Setelah didapatkan hasil tes awal dan tes akhir dari kelas kontrol dan eksperimen, maka hasil tesebut diolah dengan menggunakan rumus. Adapun hasil nilai tes awal dan tes akhir pada kelas eksperimen dan kontrol adalah sebagai berikut:

Tabel 2. Hasil Nilai Tes Awal Dan Tes Akhir Siswa Kelas Kontrol Dan Kelas Eksperimen

\begin{tabular}{|l|l|l|l|l|}
\hline \multirow{2}{*}{\multicolumn{1}{|c|}{ Analisis }} & \multicolumn{2}{|c|}{ Kelas kontrol } & \multicolumn{2}{c|}{ Kelas eksperimen } \\
\cline { 2 - 5 } & Tes awal & $\begin{array}{c}\text { Tes } \\
\text { akhir }\end{array}$ & Tes awal & $\begin{array}{c}\text { Tes } \\
\text { akhir }\end{array}$ \\
\hline Nilai rata-rata $(\overline{\mathrm{x}})$ & 19,61 & 78,66 & 37,75 & 93 \\
\hline Varians $\left(s_{2}^{2}\right)$ & 46,55 & 50,83 & 53,35 & 58,84 \\
\hline Simpangan baku $(\mathrm{s})$ & 6,82 & 7,12 & 73 & 7,53 \\
\hline Nilai maksimum & 35 & 90 & 50 & 100 \\
\hline
\end{tabular}




\begin{tabular}{|l|l|l|l|l|}
\hline Nilai minimum & 10 & 65 & 25 & 75 \\
\hline Sampel & 21 & 21 & 20 & 20 \\
\hline
\end{tabular}

\section{Uji Normalitas Data}

Pengujian normalitas data dilakukan dengan menggunakan uji chi-kuadrat, dalam penelitian ini dilakukan dua kali uji normalitas dari kelas eksperimen dan kelas kontrol.

Tabel 3. Uji Normalitas Kelas Kontrol dan Kelas Eksperimen

\begin{tabular}{|c|c|c|c|c|}
\hline Kelas & Jenis tes & $\chi_{\text {hitung }}^{2}$ & $\chi_{t a b}^{2}$ & Kesimpulan \\
\hline \multirow{2}{*}{ Kelas kontrol } & Tes awal & 4,623 & \multirow{4}{*}{7,815} & \multirow{4}{*}{$\begin{array}{l}\chi_{\text {hitung }}^{2} \leq \chi_{\text {tabel }}^{2} \\
\text { Maka data } \\
\text { berdistribusi normal }\end{array}$} \\
\hline & Tes akhir & 3,764 & & \\
\hline \multirow{2}{*}{$\begin{array}{l}\text { Kelas } \\
\text { eksperimen }\end{array}$} & Tes awal & 3,937 & & \\
\hline & Tes akhir & 3,032 & & \\
\hline
\end{tabular}

2. Uji Homogenitas

Berikut adalah daftar tabel hasil penelitian dari kelas kontrol dan eksperimen berdasarkan hasil penelitian yang dilakukan. Pengujian homogenitas data dilakukan dengan uji $\mathrm{F}$, data hasil nilai tes kelas kontrol dan kelas eksperimen adalah sebagai berikut:

Tabel 4Uji Homogenitas Tes Siswa

\begin{tabular}{|c|c|c|c|}
\hline Kelas & $F_{\text {hitung }}$ & $\mathrm{F}_{\text {tabel }}$ & Kesimpulan \\
\hline Pretest & 1,06 & \multirow[b]{2}{*}{2,14} & \multirow{2}{*}{$\begin{array}{c}\mathrm{F}_{\text {hitung }} \\
\leq \mathrm{F}_{\text {tabel }} \\
\text { Data homogen }\end{array}$} \\
\hline Post-test & 1,84 & & \\
\hline
\end{tabular}

\section{Uji N-Gain}

Deskripsi peningkatan kemampuan komunikasi matematis kelas Student Facilitator and Explaining (SFE)

Tabel 5. Uji Gain Kelas Eksperimen

\begin{tabular}{|c|c|c|c|}
\hline Skor Normal Gain & Kategori & Banyak Siswa & Persentase \\
\hline$g>0,70$ & Tinggi & 18 & $90 \%$ \\
\hline $0,30<g<0,70$ & Sedang & 2 & $10 \%$ \\
\hline$g<0,30$ & Rendah & 0 & 0 \\
\hline Jumlah & & 20 & $100 \%$ \\
\hline
\end{tabular}

Tabel 6. Uji Gain Kelas kontrol

\begin{tabular}{|c|l|l|l|}
\hline Skor Normal Gain & Kategori & $\begin{array}{l}\text { Banyak } \\
\text { Siswa }\end{array}$ & Persentase \\
\hline$g>0,70$ & Tinggi & 6 & $28 \%$ \\
\hline $0,30<g<0,70$ & Sedang & 15 & $72 \%$ \\
\hline$g<0,30$ & Rendah & 0 & 0 \\
\hline Jumlah & & 21 & $100 \%$ \\
\hline
\end{tabular}


Setelah dilakukan pengujian dengan menggunakan uji gain dapat disimpulkan bahwa persentase siswa dari kelas eksperimen yang memperoleh nilai gain dengan kategori tinggi lebih besar dari siswa dari kelas kontrol. Persentase siswa dari kelas eksperimen yang memperoleh nilai gain dengan kategori sedang lebih kecil dari siswa dari kelas kontrol. Dan tidak ada dari kedua kelas yang memperoleh nilai gain dengan kategori rendah. Maka dapat ditarik kesimpulan bahwa peningkatan kemampuan komunikasi matematis siswa yang diajarkan dengan Model Pembelajaran Student Facilitator and Explaining (SFE) lebih tinggi dari pada kemampuan komunikasi matematis siswa yang diajarkan dengan metode konvensional. Sehingga dapat disimpulkan bahwa terdapat peningkatan kemampuan komunikasi matematis siswa dengan menggunakan Model Pembelajaran Student Facilitator and Explaining (SFE).

\section{Kesimpulan}

Berdasarkan hasil penelitian yang penulis lakukan diperoleh kesimpulan bahwa: Terdapat peningkatan kemampuan komunikasi matematis siswa menggunakan Model Pembelajaran Student Facilitator and Explaining (SFE) dengan penjabaran : (1) Siswa dari kelas eksperimen dengan skor gain $>0.70$ berjumlah 18 orang dengan kategori tinggi (90\%). (2) Siswa dari kelas eksperimen dengan $0.30<$ skor gain $<0.70$ berjumlah 2 orang dengan kategori sedang (10\%) (3) Siswa dari kelas eksperimen dengan skor gain < 0.30 berjumlah 0 orang atau tidak terdapat siswa yang memperoleh skor gain dibawah 0,30 dengan kategori rendah.

\section{Daftar Pustaka}

Anggraini Astuti. 2011. Peran Kemampuan Komunikasi Matematika Teradap Prestasi Belajar Matematika Siswa. Jurnal Formatif 2 (2): 102-110, ISSN 2088-351X, hal. 104.

Arifin,Zainal. 2016. Penelitian Pendidikan. Bandung: Remaja Rosdakarya.

Arikunto, Suharsimi. 2012. Dasar-Dasar Evaluasi Pendidikan. Jakarta: Bumi Aksara.

Hamzah,Ali. 2014. Evaluasi Pembelajaran Matematika. Jakarta: Grafindo Persada.

Istarani. 2012. Model Pembelajaran Inovatif. Medan: Media Persada

Mulyono Abdurrahman. 2010. Pendidikan Bagi Anak Kesulitan Belajar, Jakarta: PT Asdi Mahasatya.

Purnama Ramlan, Dkk. 2012. Kemampuan Komunikasi Matematis dan Pembelajaran Interaktif . Jurnal UNP vol 1. No. 1.

Shoimin ,Aris. 2014. Model Pembelajaran Inovatif dalam Kurikulum. Yogyakarta: ArRuzz Media.

Susanto, Ahmad. 2013. Teori Belajar dan Pembelajaran disekolah Dasar. Jakarta: Kencana

Usman, Husaini dan Purnomo Setiadi Akbar. 2009. Pengantar Statistika. Yogyakarta : Bumi Aksara 